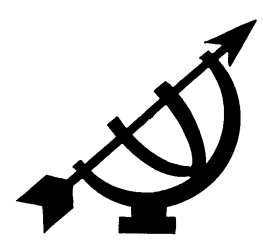

\title{
Karakteropvoeding in Suid-Afrikaanse skole
}

\author{
Jeanette de Klerk \\ Departement Opvoedingsbeleidstudies \\ Fakulteit Opvoedkunde \\ Universiteit van Stellenbosch \\ STELLENBOSCH \\ E-pos: jdkl@sun.ac.za
}

\section{Abstract \\ Character education in South African schools}

The success of a democratic society as well as effective teaching and learning presupposes virtuous people who live according to certain core values. This article focuses from a Christian perspective on character education, one of the approaches by which values can be established in South African schools. The proponents of character education accept the existence of certain core ethical values. Parents, schools and communities can work together to help children understand these values, care about them and try to live accordingly. The various methods employed by this approach to instill values in schools are discussed critically. The specific problems which the complex pluralistic South African society presents to this comprehensive approach to the instilling of values are also discussed. The critics of this approach warn against the possibility of hidden dangers of rigidity, moralising, manipulation and indoctrination which are all contraproductive to moral development.

From a Biblical-educational point of view this approach can successfully be used to instill core Biblical values, on condition that it is accompanied by credible adult role models and that due consideration is given to the uniqueness of the individuals involved. Character-education, if applied with awareness of the comprehensiveness of the approach and sensitivity to the multicultural situation, has the potential to address the moral dilemmas in South African schools. 


\section{Opsomming}

\section{Karakteropvoeding in Suid-Afrikaanse skole}

Die sukses van 'n demokratiese samelewing asook effektiewe leer en onderrig veronderstel deugsame mense wat volgens sekere kernwaardes leef. Hierdie artikel fokus vanuit 'n Christelike perspektief op karakteropvoeding as een van die wyses waarop waardes in Suid-Afrikaanse skole gevestig kan word. Die voorstanders van karakteropvoeding aanvaar die bestaan van sekere kern etiese waardes. Ouers, skole en gemeenskappe kan saamwerk om kinders te help om dié waardes te verstaan, daarvoor om te gee en hul lewe daarvolgens te rig. Die verskillende metodes waarvan die karakteropvoedingsbenadering gebruik maak, word krities bespreek. Die komplekse, pluralistiese Suid-Afrikaanse samelewing stel groot uitdagings aan hierdie omvattende benadering tot die vestiging van waardes. Die kritici van hierdie benadering waarsku teen die moontlike gevare van rigiditeit, moralisering, manupilering en indoktrinasie wat kontraproduktief is vir karakterontwikkeling.

Die benadering van karakteropvoeding kan vanuit 'n Bybelsopvoedkundige oogpunt suksesvol geïmplementeer word om kernwaardes vanuit die Skrif te vestig. Die voorwaarde is dat dit gepaard gaan met geloofwaardige volwasse rolmodelle en begrip vir die uniekheid van individue. Indien karakteropvoeding geïmplementeer word met 'n bewustheid van die omvattendheid daarvan en 'n sensitiwiteit vir die multikulturele situasie in ons land, kan dit die morele dilemmas in Suid-Afrikaanse skole help oplos.

\section{Inleiding}

'n Gebrek aan moraliteit is tans een van die dringendste probleme in Suid-Afrikaanse onderwys. Die morele krisis in die land resoneer in skole waar leerders nie respek toon vir mekaar, onderwysers of skooleiendom nie. Verder is daar 'n afwesigheid van 'n werksetiek, ongedissiplineerdheid by sowel opvoeders as leerders, 'n gebrekkige verantwoordelikheidsin en groeiende etiese ongeletterdheid op alle vlakke. Sommige skole het plekke geword waar vandalisme en dwelmhandel plaasvind, medeleerders afgeknou en selfs verkrag word, diefstal gepleeg word en waar eerlikheid, betroubaarheid en verantwoordelikheid as uitgediende begrippe beskou word (De Wet, 2003; De Wet, 2004; Prinsloo, 2005).

Die oplossing vir dié probleem is in die eerste plek nie geleë in nuwe kurrikula, meer programme of beter projekte nie, maar in deugsame 
mense wat volgens sekere basiese waardes leef. ${ }^{1}$ Die sukses van 'n demokratiese samelewing in Suid-Afrika sowel as effektiewe onderwys voorveronderstel die teenwoordigheid van sekere kernwaardes. Nóg die ideale wat in die Grondwet vervat is, nóg die visie van uitkomsgebaseerde onderwys kan gerealiseer word as dit nie gedra word deur waardes soos respek, verantwoordelikheid, selfdissipline en hardwerkendheid nie. Onderwys is in sy wese ' $n$ waarde-aangeleentheid en alles wat in die onderrigsituasie gebeur, is deursuur met waardes: "... morality cannot be excluded from the classroom, no matter how hard one tries. It is part of the very fabric of schooling" (Damon, 1988:131).

Daar is talle redes waarom die vestiging van waardes ' $n$ prioriteit in Suid-Afrikaanse skole behoort te wees, byvoorbeeld:

- Jong mense is toenemend besig om hulself en ander seer te maak.

- Waardevestiging is nodig sodat doeltreffende leer en onderrig kan plaasvind en sodat skole aangenamer werksplekke kan wees en sodat bekwame opvoeders gewerf en behou kan word.

- Akademiese uitmuntendheid en karakter kan nie van mekaar losgemaak word nie, want akademiese uitmuntendheid is gegrond in en word gedra deur 'n sterk karakter. "Academic excellence will never be achieved if we fail to integrate the maturation of mind with that of character and self" (Heath, 1994:113).

- Demokrasie steun op redelik ordentlike mense. "If we want to actualize the moral vision of the constitution, namely a future founded on the recognition of human rights, democracy, peaceful co-existence and the development of opportunities for all South Africans ... this vision will have to be interpreted and empowered by corresponding basic principles. The inculcation of these principles should therefore be one of the priorities of the education system" (De Klerk, 1998:20).

Die vraag is daarom nie of waardes gevestig moet word nie, maar wel watter waardes en hoe dit suksesvol gedoen kan word.

Hierdie artikel fokus vanuit 'n Christelike perspektief op een van die wyses waarop waardes in skole gevestig kan word, naamlik

1 In die spreektaal word waardes bo deugde verkies, omdat eersgenoemde 'n meer positiewe gevoelswaarde as deugde het (Vosloo, 1995:273). 
karakteropvoeding. Die mens se morele waardes is gegrond in sy geloofsoortuiging en kan nie daarvan losgemaak word nie. Fowler et al. (1990:52) verduidelik dit soos volg: “... educational values are grounded in life values developed in the context of a world view at the heart of which is a religious commitment of one kind or another". Die beginpunt vir die vestiging van waardes en die bou van karakter vanuit 'n Christelike perspektief is Visio Dei (Thomas Aquinas), die visie van God, waardeur die realiteit van God die kern word waarom alles draai. Hierdie geheel anderse gerigtheid of fundamentele transformasie gee dan aan die mens 'n nuwe identiteit as nuwe, verloste skepsel in Christus. Jou nuwe identiteit bepaal jou karakter en die vrugte van die identiteit begin dan groei as deugde. Deugde word konkreet gemaak deur norme en waardes. In religieuse sin beteken dit 'n nuwe lewe wat uitbot (Du Toit, 2005).

Hierdie siening is egter vir talle opvoedkundiges, wat morele opvoeding in skole wil losmaak van enige geloofsoortuiging, totaal onaanvaarbaar.

For many moral educationists, the religion-morality issue functions as a red flag. Leaders in the field have, over the last number of decades, expended a great deal of effort in detaching moral education from religion, both conceptually and practically (Fernhout, 1989:187).

Fernhout (1989:188) argumenteer ook dat morele opvoeding in geloof begrond is en dat die fokus daarom nie behoort te val op die verhouding tussen morele opvoeding en religie nie, maar wel op die verhouding tussen morele opvoeding en geloof. Geloof kan nie losgemaak word van moraliteit nie, want "... faith informs our worldview. In Christian ethical thought, the concept of vision, rather than worldview, is sometimes used to express the idea that faith informs a way of looking at life in this world, including moral life" (Fernhout, 1989:188). Die begronding van morele opvoeding in ' $n$ hoër geloofsdimensie word ook deur Kohlberg (1981:321) erken as hy beweer dat die antwoord op die vraag "Why be moral at all?" op 'n geloofsvlak lê: "Faith grounds the very possibility of making a moral judgement or acting morally" (Power \& Kohlberg, 1980:365). Lickona (2001) formuleer die verband tussen morele opvoeding en geloof soos volg:

We must help students understand the three interrelated purposes of their lives: to save their souls and help others to heaven; to build the kingdom of God, and to develop the character of Christ. 
In 2 Petrus 1:5 (New Living Translation) word die verband tussen moraliteit en geloof soos volg verwoord: "Then your faith will produce a life of moral excellence."

Die Christelik-Nasionale Onderwyswet van 1967 het die Christelike aard en karakter van onderwys vooropgestel en die vraag kan met reg gevra word tot watter mate daar toe wel aan karakteropvoeding in skole gestalte gegee is. Binne die Christelike denkraamwerk gaan opvoeding oor die vestiging van Christelike waardes. Die gebruik van die term Christelik is egter geen waarborg dat alle onderwys wat onder die vaandel plaasgevind het, gerig was op die vaslegging van Christelike waardes nie. Daar was talle Christenonderwysers wat vanuit hul Christelike roeping hul doelbewus beywer het vir die ontwikkeling van 'n Christelike karakter by leerders in ooreenstemming met die opdrag uit die Skrif om leiding aan jongmense te gee oor hoe hulle moet leef. Daar was egter ook talle onderwysers wat nie die vestiging van Christelike deugde as deel van hul taak as onderwysers gesien het nie. In dié verband is Leatt (aangehaal in Schoeman 2000:166) se waarskuwing aan Christene baie relevant: "(to be) especially alert where Christianity itself and Christian symbols are used as window-dressing ..."2

\section{2. 'n Analise van karakteropvoeding}

\subsection{Filosofiese uitgangspunt en definiëring}

In ooreenstemming met die paradigmaskuif in die etiek vanaf "Wat is goeie gedrag en wat is reg en verkeerd?" na "Wat konstitueer 'n goeie persoon?" val die klem by karakteropvoeding op die karakter en die deugde van die morele agent. Plato het die vier kardinale deugde, naamlik wysheid, regverdigheid, moed en selfbeheersing beklemtoon. Denkers soos Maclntyre (1984) en Smedes (1990), in navolging van Aristoteles, is oortuig daarvan dat 'n deugde-etiek hoop kan bring in morele chaos. Maclntyre vervang die vraag "Hoe sal ek besluit wat om te doen?" met "Watter soort mense behoort ons te wees?"

Karakteropvoeding is die doelbewuste poging van skole, families en gemeenskappe om jongmense te help om etiese kernwaardes te verstaan, daarvoor om te gee en daarvolgens op te tree (Lickona,

2 Die onderskeid wat Ellul (1975:1-17) tref tussen die Christene wat werklik in 'n geloofsverhouding met Christus staan en aan Hom toegewyd leef en dié wat kultuur-Christene is, is hier van toepassing. 
1996:93). Dit behels "... knowing the good, loving the good, and doing the good" (Lickona, 1991:51). Voorstaanders van dié benadering, onder andere Lickona (1996), Wynne en Ryan (1992), Heath (1994) en Kilpatrick (1992), is dit eens dat sekere etiese kernwaardes soos respek, verantwoordelikheid, eerlikheid, integriteit en naasteliefde deur verskillende gemeenskappe, kulture en gelowe erken word. Die etiese kernwaardes

... affirm our human dignity, promote the good of the individual and the common good, and protect our human rights. They meet the classic ethical tests of reversibility and universalizability. They define our responsibilities in a democracy, and they are taught by all enlightened creeds (Lickona, 1993:9).

In ooreenstemming met Kant, wat 'n universele, rasionele etiek wou skep met etiese beginsels waaroor alle mense saamstem, word daar dus by karakteropvoeding van die veronderstelling uitgegaan dat sekere etiese kernwaardes universeel erken word. Hierdie waardes stem ooreen met die waardes wat in die Skrif beklemtoon word. Vir die Christen word individuele waardes oorweeg in die lig van geloofswaardes. Eyre en Eyre (1993:27) definieer die waardes soos volg: "A true and universally acceptable 'value' is one that produces behavior that is beneficial both to the practitioner and to those on whom it is practiced." Heenan (2002:27-31) praat van hoeksteenwaardes:

Cornerstone values are sets of consistent, universal and transcultural principles which inform and direct our actions and activities ... cornerstone values affirm our human dignity, promote the good of the individual and society and are the foundation of good character and therefore responsible citizenship and civil society.

Van der Ven (1998:379) brei egter heelwat uit op Lickona se beskouing oor karakteropvoeding:

Character formation should be based on the three-way interrelatedness of passions, goods, and reasons, as we learn from the ancients, especially Plato and Aristotle. Then this interrelatedness must be interpreted from the perspective of interactionism between person and situation, as we learn from Dewey. Further, this interactionism, being linguistic in nature, has to be understood in terms of its narrative structure.

Karakteropvoeding is daarom 'n komplekse benadering, omdat deugde nie onbuigbare, rigiede riglyne is nie, die verskillende fasette 
van spesifieke situasies en unieke individue gedurig in aanmerking geneem moet word en die narratiewe aard van alle interaksies gedurig inspeel in situasies. "Virtues are orientations, not fixed guidelines, and as such guarantee the uniqueness of both persons and situations" (Van der Ven 1998:343).

Die Christenouer en -onderwyser staan voor die opdrag om aan 'n jongmens leiding te gee oor hoe hy moet leef (Spr. 22:6). Dit beteken om nie alleen die kernwaardes in die Skrif te ken nie, maar daarvoor om te gee en daarvolgens te leef. Die kernwaardes wat deur die Skrif beklemtoon word, slaag die etiese toets van omkeerbaarheid (Matt. 7:12). Omdat die mens in sonde ontvang en gebore word en van nature geneig is tot die kwaad, behoort morele vorming doelbewus in gesinne, families, skole en godsdienstige gemeenskappe plaas te vind, waar kinders oor 'n lang tyd opgevoed en ingeoefen word om deugsame, goeie mense te word. Hulle moet die kernwaardes internaliseer en in die verskillende situasies wat mag opduik, uitleef. Mense is nooit bloot passiewe ontvangers van die waardes wat deur ouers en onderwysers aan hul voorgehou word nie, maar aktiewe skeppers van hul eie waardes wat wel verband hou met dié van hul opvoeders, maar wat ook 'n unieke, eiesoortige karakter het. Spreuke 22:6 se "Teach your children to choose the right path, and when they are older, they will remain upon it" (New Living Translation) impliseer dat ouers die verpligting het om Christelike waardes aan hul kinders voor te leef en te onderrig. Dit impliseer egter nie indoktrinasie en determinisme nie, aangesien die keuse-element steeds teenwoordig is.

\subsection{Karakteropvoeding is 'n omvattende benadering}

Kinders se moraliteit is die produk van affektiewe, kognitiewe en sosiale kragte wat saamsmelt tot ' $n$ steeds groeiende morele bewussyn. "Morality depends upon the orchestration of human caring, objective thinking, and determined action ... Morality is neither good motives nor right reason nor resolute action; it is all three" (Hersh et al., 1980:2). Pipher (1996:147) stem hiermee saam: "Character implies both thought and feeling, history and action." Karakteropvoeding is ' $n$ omvattende benadering tot die vestiging van waardes waar die kognitiewe en affektiewe met gedragsaspekte gekombineer word en behels daarom reflektering, doelgerigte optrede, gemotiveerdheid tot morele aksie en die vorming van goeie gewoontes oor tyd. Karakteropvoeding sluit in dat leerders waardes op kognitiewe vlak verstaan, dat hulle hulself op affektiewe vlak daaraan verbind, hul lewe in ooreenstemming daarmee bring en 
daarvolgens optree. Volgens Lickona (1993:9) sluit die kognitiewe aspek van karakter die volgende in:

... awareness of the moral dimensions of the situation at hand, knowing moral values and what they require from us in concrete cases, perspective-taking, moral reasoning, thoughtful decisionmaking, and moral self-knowledge. All these powers of rational moral thought are required for full moral maturity and citizenship in a democracy.

Die emosionele sy van karakteropvoeding behels "conscience (the obligation to do what one judges to be right), self-respect, empathy, loving the good, self-control, and humility (a willingness to both recognize and correct out moral failings)" terwyl morele aksie vra vir "competence (skills such as listening, communicationg, and cooperating)." Juis omdat moraliteit so kompleks en multi-dimensioneel is, behoort etiese teorieë ook veelvlakkig en omvattend te wees.

\subsection{Metodes geïmplementeer deur die karakter- opvoedingsbenadering}

Omdat karakteropvoeding so 'n omvattende en veelvlakkige benadering is, word daar van 'n verskeidenheid metodes gebruik gemaak. Karakteropvoeding is nie beperk tot sekere periodes of sekere onderwysers nie en ook nie tot een metode nie, maar behoort die totale skoollewe as 't ware te deursuur. "If our goal is to promote good character in youth, such as the core values of trustworthiness, respect, responsibility, caring, fairness, and good citizenship, then we should welcome all the best methods for achieving these goals" (Kirschenbaum, 2000:14). Elke faset van die skoollewe, soos onder andere die opvoeder se voorbeeld, morele dissipline, die akademiese kurrikulum, die wyse waarop die skool bestuur word, die verhouding met die ouers en die projekte in die gemeenskap, dra by tot karakteropvoeding. Geïsoleerde karakter opvoedingsprogramme kan die eerste stap wees in die regte rigting, maar dit kan nooit so effektief wees soos 'n holistiese benadering waar karakteropvoeding op 'n natuurlike wyse in elke aspek van die skoollewe geïntegreer word nie. "Teaching moral values doesn't work if teachers try to 'make it a big deal' or 'have a separate class about it"' (Williams, 1993:22). Leming (1993a:69) waarsku in dié verband: "Didactic methods alone are unlikely to have any significant or lasting effect on character." 
Die vertel van verhale is 'n kragtige manier waarvan karakteropvoeding gebruik maak om kernwaardes te vestig. Maclntyre (1984:114) beweer dat in alle klassieke en heroïese samelewings "... the chief means of moral education is the telling of stories." Kilpatrick (1992:197) stem hiermee saam: "Morality needs to be set within a storied vision if it is to remain morality" en Bandura (1986:52) beweer: "Storytelling functions as a kind of modeling, ... by offering an example with which the listeners or readers can identify." Ook Jesus het primêr gelykenisse (stories) gebruik om kernwaarhede oor te dra.

By karakteropvoeding is die medium die boodskap, en daarom is die opvoeder as rolmodel baie belangrik. "By personifying a strong morality teachers also provide an opportunity for the student to make a positive identification with an inspiring model ... When there are disjunctions between a teacher's word and deeds, the moral message is sabotaged" (Damon \& Colby, 1996:36). Almal wat betrokke is by die leerders - die onderwysers, die persone wat sport afrig, die sekretaresses, busbestuurders en skoolopsigters - behoort betrokke te wees by en eienaarskap te aanvaar van karakteropvoeding, nie alleen deur die modellering van die kernwaardes in hul eie gedrag nie, maar ook deur die aanmoediging van leerders om die waardes te demonstreer, want "... moral principles are learned indirectly from others around us, who serves as exemplars" (Meilander, 1978:212). Die morele leierskap van die onderwysers en die skoolbestuur is onmisbaar by die vestiging van waardes in skole. Ook historiese en literêre figure in die leerplan kan dien as bronne van morele modellering. Die opvoeder as rolmodel en mentor is in ooreenstemming met die rolle wat deur die onderwysdepartement voorgeskryf word vir opvoeders in Suid-Afrika, maar hierdie feit maak dit nog nie 'n realiteit in die praktyk nie.

Karakter ontwikkel in 'n sosiale netwerk van verhoudings en die manier waarop mense mekaar behandel en teenoor mekaar optree, is die kragtigste morele invloed wat die skool kan uitoefen. Die skool het daarom 'n belangrike rol as omgeegemeenskap. Dewey (aangehaal in Archambault, 1964:431) stel dit soos volg: "The best and deepest moral training is that which one gets by having to enter into proper relations with others ... Present educational systems, so far as they destroy or neglect this unity, render it difficult or impossible to get any genuine, regular moral training." Vanuit die Christelike lewensbeskouing is nie alleen liefde tot God nie, maar ook naasteliefde die kerngebod en daarom behoort 'n omgeegemeenskap een van die kenmerkende eienskappe van onderwys 
te wees. Navorsing deur Resnick (aangehaal in Lickona, 2001) toon dat hoe meer skole daarin slaag om omgeegemeenskappe te vorm, hoe meer kom die volgende positiewe uitkomste voor: leerders hou meer van skool en voel minder eensaam; het meer empatie met ander; is gemotiveerd om hulpvaardig te wees; altruïstiese gedrag kom meer dikwels voor asook sterker gevoelens van sosiale bevoegdheid; jeugmisdaad neem af; daar is groter akademiese selfagting en alkohol en marijuana word minder gebruik. Wanneer leerders met warmte en respek behandel word, is hulle meer geneig om ook so teenoor ander op te tree. Uit hierdie omgeeverhoudings ontwikkel die behoefte om te wil leer asook die behoefte om ' $n$ "redelik goeie" mens te wees - met ander woorde karakterontwikkeling vind plaas.

Kilpatrick (1992:226) beklemtoon die rol van die morele klimaat van 'n skool: "The ethos of a school, not its course offerings, is the decisive factor in forming character. The first thing we must change is the moral climate of the schools themselves." 'n Morele gemeenskap in die klas word kenmerk deur respek, omgee, regverdigheid en die uitoefening van morele dissipline. Dissipline verskaf die morele kode wat dit moontlik maak vir die klas om as 'n klein gemeenskap te kan funksioneer. Sonder dissipline kan effektiewe onderrig en leer nie plaasvind nie en lei karakterontwikkeling skade. Morele dissipline vereis konsekwente en regverdige optrede deur die opvoeder. "Clearly enforced rules, and an orderly school environment and classroom climate contribute to the development of character and prosocial behaviors" (Leming, 1993b:23). Ongelukkig is daar talle skole in Suid-Afrika waar effektiewe leer nie kan plaasvind nie, omdat daar 'n afwesigheid is van morele dissipline en leerders nie die legitieme gesag van die onderwyser, die regte van medeleerders en regverdige skoolreëls respekteer nie. Vanuit 'n Bybelse perpsektief behoort dissipline in liefde plaas te vind en die doel daarvan is om te herstel en te korrigeer (Van Dyk, 2000:239-240).

'n Demokratiese klasatmosfeer is 'n voorvereiste vir karakterontwikkeling. Sodanige demokratiese klasatmosfeer word gekenmerk deur duidelike kommunikasie, kreatiwiteit, samewerking, ondersteuning, aanpasbaarheid, respek en gedeelde verantwoordelikheid. Die klem val hier nie op mislukking of negatiewe kritiek nie, maar op aanmoediging en positiewe motivering.

Karakterontwikkeling vind plaas deur middel van die kurrikulum, en al die leerareas kan hiervoor gebruik word. Die vestiging van waardes kan nie geïsoleerd van die res van die kurrikulum 
aangebied word nie, maar behoort op 'n natuurlike manier geïntegreer te word in elke aspek van die kurrikulum. Karakteropvoeding behoort ook deel te wees van sportafrigting, van die bespreking van morele dilemmas wanneer die onderwyser besig is met byvoorbeeld Macbeth of Julius Caesar, of wanneer die vredesverdrag van die Eerste Wêreldoorlog bespreek word. Schumacher (1974:76) beklemtoon die feit dat ál die skoolvakke die metafisiese dimensie moet hanteer en waardes moet vestig. Damon (1988:151) stel voor dat daar van die Sokratiese metode gebruik gemaak word om waardes in die geskiedenis of in literêre werke te identifiseer, om sodoende morele refleksie en morele dialoog aan te moedig.

Karakteropvoeding vereis dat leerders geleenthede kry tot morele aksie. Aristoteles het gesê:

But the virtues we do acquire by first exercising them, just as happens in the arts. Anything that we have to learn to do we learn by the actual doing of it: people become builders by building and instrumentalists by playing instruments. Similarly, we become just by performing just acts, temperate by performing temperate ones, brave by performing brave ones (Van der Ven, 1998:384).

Leerders behoort binne en buite die skool geleenthede te kry om waardes soos verantwoordelikheid, respek en omgee as 't ware in te oefen en hulle direkte betrokkenheid by gemeenskapsprojekte kan hier 'n belangrike rol speel.

Sowel morele refleksie as morele gewoontevorming is nodig vir die ontwikkeling van karakter en die een behoort nie ten koste van die ander beklemtoon te word nie. "The heart of moral growth is not simply acquiring good habits or insightful reflectiveness; rather it is developing the capacity to move easily between them" (Damon \& Colby, 1996:34).

Suksesvolle karakteropvoeding sluit 'n betekenisvolle en uitdagende akademiese kurrikulum in waar alle leerders gerespekteer en gehelp word om sukses te behaal. Daar is 'n sterk wedersydse ondersteunende verhouding tussen karakteropvoeding en onderrig en leer, "... character education creates an environment designed to enhance the effectiveness of teaching and learning" (DeRoche \& Williams, 2001:xv). Die twee beïnvloed mekaar wedersyds, want indien karakteropvoeding in skole so plaasvind dat daar wedersydse respek tussen leerders en opvoeders bestaan, is die moontlikheid vir doeltreffende onderrig en leer groter. Aan die ander kant word 
karakter gebou wanneer leerders gehelp word om akademies hul bes te doen. 'n Sterk karakter is nodig vir sowel interpersoonlike verhoudings as akademiese prestasie en die valse digotomie tussen karakteropvoeding en akademie behoort nie te bestaan nie. Morele opvoeding mag nie geïsoleer word van die res van die kurrikulum nie en die ontwikkeling van 'n sterk karakter kan nie losgemaak word van akademiese voortreflikheid nie.

Ouers en persone uit die gemeenskap behoort as volle vennote die karakteropvoedingspoging te steun, want die betrokkenheid van ouers, geloofsgemeenskappe asook die breër gemeenskap is onmisbaar.

All the institutions that come in contact with young people must play a constructive role in their moral growth. Schools cannot shoulder the entire responsibility themselves; nor can they contribute in any meaningful way if they set themselves apart from the rest of the community (Damon \& Colby, 1996:35).

Noddings (1984:171) is dit eens: "Moral education is a communitywide enterprise and not a task exclusively reserved for home, church or school." Ianni (1988) se navorsing het getoon dat die beste voorspeller van 'n kind se gedrag die mate is waartoe al die betekenisvolle rolspelers en instansies in sy/haar lewe 'n gemeenskaplike stel norme vir gedrag daarstel.

Boyer (1995:49) beklemtoon: “... it is not the school that's failed, it's the partnership that's failed, with schools taking on responsibilities that families and communities and religious institutions once assumed." Christen-ouers behoort nóú betrokke te wees en 'n inspraak te lewer by die formulering van die kernwaardes van die skool, sowel by die praktiese projekte in die gemeenskap waarby die skool betrokke is, as by die hantering van morele probleme. "Sex and drug education programs that elicit help from peers, parents, and the community have been found to be the most effective in changing students behavior" (Leming, 1993b:69).

Navorsing (Green, 2004:259) toon dat opvoeders in Suid-Afrika die ontwikkeling van karakter en die vestiging van waardes ongelukkig meer assosieer met die beheer van ongewenste gedrag as met die aktiewe en doelbewuste bevordering van gewenste gedrag. 


\subsection{Die problematiek van karakteropvoeding in Suid- Afrikaanse skole}

Die vraag wat na vore tree, is of dit in die lig van die kompleksiteit van die sosiale, politieke en kulturele diversiteit in Suid-Afrika enigsins moontlik is om van etiese kernwaardes te praat en of karakteropvoeding in skole nie miskien eerder 'n manier moet wees om die morele tekortkomings te hanteer nie.

There is an urgent need for a coherent moral voice that cuts through the moral pluralism of our diverse society. This coherence requires a consensus about certain core values that virtually everyone in the community agrees need to be passed on to the next generation. Although the nature of the consensus will vary to some extent from one community to another and complete consensus will not be possible even within most communities, there are some core values that most adults in most communities will have in common" (Damon \& Colby, 1996:34, 35).

Kilpatrick (1992:117) beaam die siening: “... a country with many racial and ethnic groups can remain relatively peaceful for decades if these groups share the same language and values." Fernhout (1989:97) se beskrywing van 'n pluralistiese samelewing onderstreep die kompleksiteit en die uitdagings van morele opvoeding in so 'n samelewing:

... since education is intimately connected to people's faith orientations, it is essential in a pluralistic society that people have genuine choices that reflect their repective beliefs and commitments. Generally speaking, the presence of real choices does not hinder democracy but is integral to it. 'Social cohesion' is best served when people become committed within the context of their view of life, to the well-being of society as a whole.

Volgens Fernhout behoort morele opvoeding in 'n pluralistiese samelewing dus nie in een spesifieke perspektief op die lewe of een geloofsoortuiging gegrond te wees nie, maar moet elkeen vry wees om 'n keuse te kan maak vanuit hul eie oortuiging.

Die strewe na en aanvaarding van etiese kernwaardes soos deur karakteropvoeding voorgestaan word, kan veral in die SuidAfrikaanse konteks, moontlik polarisering en konflik tussen die verskillende groepe voorkom. Die vraag is egter watter waardes as saambindende waardes in Suid-Afrikaanse skole behoort te dien. Die regering beklemtoon in die Manifes oor Waardes en Demokrasie 
(2001:iv-v) die volgende gemeenskaplike waardes vir SuidAfrikaanse Skole: demokrasie, sosiale regverdigheid en billikheid, gelykheid, nie-seksisme en nie-rassisme, ubuntu, 'n oop samelewing, verantwoordelikheid, die beginsel van 'n regstaat (rule of law), respek en rekonsiliasie. Hierdie "waardes" is eintlik 'n mengsel van waardes, idees en sosiale strategieë wat in die teken van nasiebou, sosiale geregtigheid en versoening staan. Of hierdie waardes in ooreenstemming is met die waardes wat die meerderheid ouers graag in skole gevestig sou wil sien, is 'n ope vraag. By die drie skole waar ek by karakteropvoedingsprogramme betrokke was en waar ouers, onderwysers en leerders self kernwaardes vir hul skole geïdentifiseer het, is slegs respek en verantwoordelikheid wat in die Manifes genoem word, beklemtoon. Beckmann en Nieuwenhuis (2004:460) kom tot dieselfde gevolgtrekking:

Of die waardes [wat in die Manifes voorkom] egter die karakter vorming wat in opvoeding beoog word voldoende aanspreek, bly 'n ope vraag wat onderwerp behoort te word aan debattering en dit is uiteraard moontlik dat mense ander waardes ook as essensieel mag sien ... Dit behoort bloot as riglyn gesien te word wat voldoende ruimte behoort te laat om ander partikulêre gemeenskapswaardes te tolereer.

Die wyse waarop die regering probeer om hierdie waardes te bevorder is ongelukkig soms kontraproduktief: "Die regering moet dalk kyk of die arrogante en dreigende houding wat die onderwysdepartement soms in omsendbriewe aanneem om waardes op gemeenskappe af te dwing, nie juis teen die bevordering van nasionale eenheid werk nie" (Anon., 2005:14). Die Manifes oor Waardes en Demokrasie is gegrond in die taal van menseregte wat ' $n$ internasionale taal is en neutraal staan tot enige geloofsoortuiging. Habgood (1990:109, 110) wys egter daarop dat die taal van menseregte histories afhanklik is van 'n implisiete moraliteit wat nie losgemaak kan word van religieuse oortuigings nie: "Thus when we ask what it is which undergirds such assertions as the equality of all people or the dignity of the individual, it is difficult to avoid tracing the connections back to traditional Protestant ideas about a personal relationship with God."

'n Vraag wat ook na vore tree, is of waardes hoegenaamd van bo af voorgeskryf kan word deur 'n regering. Horn (2002:20, 21) stem nie saam nie: "Neerlegging deur die staat van die waardes wat moet dien om rigting en sin aan die lewe te gee, en die aandring deur die staat dat die waardes deur almal aanvaar moet word, is verkeerd". 
Die redes vir haar standpunt is dat geen staat die reg het om die mens te ontneem van sy/haar godgegewe vryheid om self lewenswaardes te kies nie en dat die staat net kan aandring dat skole leiding verskaf in die vorming van deugde wat die grondslag van wetsgehoorsaamheid vorm. Sy wys verder daarop dat die voorskryf van spesifieke lewenswaardes aan skole in die Manifes neerkom op sosiale manipulasie en dat karakteropvoeding 'n beter alternatief is: "Die weg tot sosiale geregtigheid is nie deur sosiale manipulasie en die kweking van politieke en sosiale bewussyn onder kinders nie. Sosiale harmonie en geregtigheid is gegrond in persone van goeie karakter" (Horn, 2002:21).

Dit is duidelik dat die belangrike vraag waaroor daar nog geen konsensus is nie en waaroor nog lank en dringend gedebatteer sal word, die volgende is: Wie se waardes of watter deugde behoort in Suid-Afrikaanse skole bevorder te word? In privaat Christenskole en huisskole is die beklemtoning van Christelike waardes en deugde nie 'n probleem nie en kan dit openlik uit die Skrif as die gesaghebbende Woord van God geneem word. By staatskole het ouers en beheerliggame die reg om die etos van die skool te bepaal en Christenouers het ook die verantwoordelikheid om toe te sien dat die waardes wat op skool gevestig word, ooreenstem met die waardes van hul Christelike lewensfilosofie. Die Christenouer wat die doopbelofte afgelê het, kan egter nooit ontkom aan die opgawe om in die huis die morele grondslag van die kind se waardestelsel te lê nie.

\subsection{Struikelblokke in die weg van karakteropvoeding in Suid- Afrikaanse skole}

Die sukses van karakteropvoedingsprogramme hang tot 'n groot mate daarvan af of daar ondersteuning vanuit die groter gemeenskap is en of die waardes wat in die skool gevestig word, ooreenstem met die waardes van die gemeenskap (Brooks \& Kann, 1992). Omdat die kwaliteit van kinders se morele optrede gevorm word deur die kwaliteit van hul verhoudings, speel die verhouding met die onderwyser ' $n$ rol in die vestiging van waardes en die ontwikkeling van deugde, maar dié verhouding met die primêre opvoeders (ouers), vriende en ander persone uit die gemeenskap is ook baie belangrik.

Uit navorsing (De Klerk, 2003:55-57) blyk dat daar talle faktore is wat die vestiging van waardes in skole verhinder. Die faktore sluit die volgende in: 
- Faktore wat verband hou met diverse waardesisteme. Die huis, skool, gemeenskap en media se waardes bots byvoorbeeld dikwels.

- Struikelblokke wat primêr in die onderwysers gesetel is, soos onder andere dat hulle dikwels onvoldoende toegerus is vir waarde-opvoeding en dikwels nie eienaarskap daarvoor aanvaar nie, dat hulle nie goeie rolmodelle is nie en dat hul administratiewe lading te swaar is. Daar is dikwels 'n gebrek aan morele leierskap in die onderwys. Swak en inkonsekwente skooldissipline is kontraproduktief.

- Gemeenskap en ouerhuis vorm dikwels ook struikelblokke: Talle ouers is apaties, onbetrokke en swak rolmodelle, daar is 'n gebrek aan gemeenskaplike kernwaardes in die gemeenskap en talle leerders woon in gemeenskappe waar misdaad "betaal".

- Daar is 'n generasiegaping tussen die jonger (meer moderne en gesofistikeerde) geslag en die ouer (meer tradisionele) geslag. Dié feit veroorsaak dat talle leerders nie hul onderwysers as rolmodelle beskou nie, maar neersien op hulle.

- Struikelblokke by die leerders self sluit die volgende in: egosentrisme en die afwesigheid van respek vir ander se regte en waardes, gebrekkige selfdissipline, en sterk groepdruk. Hierdie aspekte is dikwels kontraproduktief vir die vestiging van waardes.

\section{Kritiek teen die karakteropvoedingsbenadering}

Van der Ven (1998:343) wys daarop dat:

The adversaries fear that character formation will take us back to the 'dark ages', to the educational methods of the past that were characterized by rigid training programs, fixed rules, punitive habit formation, and inhuman coercion. They suspect character formation of being made up of the 'three M's', which are moralizing (by invoking guilt), manipulating (by reward and punishment), and modeling (expecting the child to be as we are and to act as we do).

Daar word dus gewaarsku teen die gevaar dat karakteropvoeding kan ontaard in die afdwing van rigiede reëls en regulasies, oormatige moralisering, onmenslike manipulering van kinders en die verlies van eie identiteit en uniekheid by kinders wanneer daar gepoog word om van hulle "klone" van hul modelle te maak. 
Die belangrikste kritiek teen karakteropvoeding, veral vanuit die waarde-uitklaringsbenadering en die kognitiewe ontwikkelingsbenadering, is dat dit ' $n$ onkritiese benadering is wat nie leerders se kritiese denke ontwikkel nie. Volgens Nash (1997:50) berei karakteropvoeding leerders nie voor vir deelname aan 'n postmoderne samelewing nie, omdat hulle nie geleer het om op rasionele wyse oor morele vraagstukke te argumenteer nie, nie gemaklik voel met kompeterende sienings van reg en verkeerd nie en nie weet hoe om kompromieë aan te gaan nie.

Een van die ernstigste argumente wat dikwels teen karakteropvoeding gebruik word, is dat dié benadering in die verkeerde hande misbruik kan word en kan disintegreer tot outoritêre indoktrinasie. Damon (1988:145) is veral sterk gekant teen moontlike indoktrinasie deur karakteropvoeding, omdat dié benadering volgens hom ondemokraties is en nie genoegsaam ingestel is op morele redenering nie en leerders nie aktief kan deelneem aan groepsgesprekke waar verskillende standpunte gestel word nie. Die deugde van byvoorbeeld hardwerkendheid en gehoorsaamheid kan ook vir twyfelagtige doeleindes aangewend word. Hiervan is euwels van konsentrasiekampe 'n ongelukkige voorbeeld.

Die feit dat talle voorstaanders van karakteropvoeding deeglik bewus is van die potensiële gevare is duidelik uit die "Cornerstone Value"-benadering wat gekenmerk word deur:

The encouragement of open discussion of the alternatives

The realistic examination of the consequences of the alternatives

The acknowledgement that students will make their own decisions (Heenan, 2002:71).

Dit is dus duidelik dat karakteropvoeding nie sonder groot omsigtigheid en nadenke in skole ingevoer behoort te word nie en dat die vorming van outonome morele denke 'n integrale deel daarvan moet vorm.

\section{Gevolgtrekking en slot}

Volgens die morele filosoof, Alasdair Maclntyre (1984), het die mens van die twintigste eeu grootliks sy/haar konsep van moraliteit verloor en hy vergelyk die morele verval van die moderne wêreld met dié tydens die val van die Romeinse Ryk. Die verlies van die teleologiese karakter van die lewe het volgens hom tot 'n morele 
impasse in 'n gefragmenteerde samelewing gelei. "What matters at this stage is the construction of local forms of community within which civility and the intellectual and moral life can be sustained through the new dark ages that is already upon us" (Mclntyre, 1984:263). Indien karakterontwikkeling in Suid-Afrikaanse skole 'n prioriteit word, kan dit 'n deurslaggewende bydrae lewer tot die vorming van gemeenskappe waar die intellektuele en morele lewe van die samelewing beskerm en uitgebou kan word. Die teendeel is egter ook waar. Indien leerders in Suid-Afrika nie selfdissipline en respek ontwikkel nie, sal die probleem van verkragting en MIVIVIGS voortduur; indien hulle nie leer om konsekwent regverdig en menswaardig op te tree teenoor ander nie, sal afknouery, geweld en misdaad nie verminder nie; indien hulle nie die selfdissipline en deursettingsvermoë ontwikkel wat nodig is vir suksesvolle studie nie, sal akademiese opleiding mettertyd geloofwaardigheid verloor.

\section{Geraadpleegde bronne}

ANON. 2005. Skole vies oor omsendbriewe. Die Burger: 14, 30 April.

ARCHAMBAULT, R.D., red. 1964. John Dewey on Education. New York: Random House.

BANDURA, A. 1986. Social foundations of thought and action: a social cognitive theory. Englewood Cliffs: Prentice Hall.

BECKMANN J. \& NIEUWENHUIS J. 2004. Die onderwysmanifes oor waardes en demokrasie in die onderwys: 'n fundering of flirtasie met waardes? South African Journal of Education, 24(1):55-63.

BOYER, E.L. 1995. The basic school: a community of learners. Princeton: Carnegie Foundation for the Advancement of Teaching.

BROOKS, D.B. \& KANN, M.E. 1992. Value-added education. American School Board Journal, 179:24-27.

DAMON, W. 1988. The moral child. New York: Free Press.

DAMON, W. \& COLBY, A. 1996. Education and moral commitment. Journal of Moral Education, 25(1):31-37.

DE KLERK, J.A. 2003. Die kompleksiteit van morele opvoeding in SuidAfrikaanse skole. Nederduitse Gereformeerde Teologiese Tydskrif, 44(1 \& 2):47-60.

DE KLERK, J.A. 1998. Reappraisal of character education in a progressive postmodernist era. South African Journal of Education, 18(1):19-24.

DEPARTMENT OF EDUCATION. 2001. Manifesto on values, education and democracy. Pretoria: Staatsdrukker.

DE WET, C. 2003. Free State educators' perceptions of the scope of learner crimes. South African Journal of Education, 23(3):168-175.

DE WET, C. 2004. The extent and causes of learner vandalism at schools. South African Journal of Education, 24(3):206-211.

DEROCHE, E.F. \& WILLIAMS, M.M. 2001. Educating hearts and minds: a comprehensive character education framework. Thousand Oaks: Corwin Press.

DU TOIT, D.A. 2005. Persoonlike mededeling aan die outeur. 
ELLUL, J. 1975. The new demons. Lodon: Mowbrays.

EYRE, R. \& EYRE, L. 1993. Teaching your children values. New York: Simon \& Schuster.

FERNHOUT, H. 1989. Moral education as grounded in faith. Journal of Moral Education, 18(3):186-198.

FOWLER, S., VAN BRUMMELEN, H.W. \& VAN DYK, J. 1990. Christian schooling education for freedom. Potchefstroom: PU for $\mathrm{CHE}$.

GREEN, L. 2004. Nurturing democratic virtues: educators' practices. South African Journal of Education, 24(4):254-259.

HABGOOD, J. 1990. Are moral values enough? British Journal of Educational Studies, 38:106-115.

HEATH, D. 1994. Schools of hope: developing mind and character is today's youth. San Francisco: Jossey Bass.

HEENAN, J. 2002. Building character through cornerstone values: how schools can teach attitudes and values. Invercargill: The New Zealand Foundation for Character Education.

HERSH, R.H., MILLER, J.P. \& FIELDING, G.D. 1980. Models of moral education: an appraisal. New York: Longman.

HORN, I. 2002. Die hersiene kurrikulum 2005 - verbetering of nie? Roeping en Riglyne, 19-22, Mei.

IANNI, F. 1988. The structure of experience. New York: Free Press.

KILPATRICK, W.K. 1992. Why Johnny can't tell right from wrong and what we can do about it. New York: Simon \& Schuster.

KIRSCHENBAUM, H. 2000. From values clarification to character education: a personal journey. Journal of Humanistic Counseling, Education \& Development, 39(1)4-17, Sept.

KOHLBERG, L. 1981. Essays on moral education. Vol 1: The philosophy of moral development. New York: Harper \& Row.

LEMING, J.S. 1993a. Character education: lessons from the past, models for the future. Camden: Institute for Global Ethics.

LEMING, J.S. 1993b. In search of effective character education. Educational Leadership, 51(3):63-71.

LICKONA, T. 1991. Educating for character: how schools can teach respect and responsibility. New York: Bantam.

LICKONA, T. 1993. The return of character education. Educational Leadership, 51(3):6-11.

LICKONA, T. 1996. Eleven principles of effective character education. Journal of Moral Education, 25(1):93-100.

LICKONA, T. 2001. What is effective character education? Presentation at the Stony Brook School Symposium on Character.

MacINTYRE, A. 1984. After virtue: a study in moral theory. Notre Dame: University of Notre Dame Press.

MEILANDER, G. 1978. The taste for the other: the social and ethical thought of C.S. Lewis. Grand Rapids: Eerdmans.

NASH, J.R. 1997. Answering the "Virtuecrats": a moral conversation on character education. New York: Teachers College Press.

NEW LIVING TRANSLATION. 1996 TouchPoint Bible. Wheaton: Tyndale House.

NODDINGS, N.1984. Caring: a feminine approach to ethics and moral education. Berkeley: University of California Press. 
PIPHER, M.A. 1996. The shelter of each other: rebuilding our families. New York: Ballantine Books.

POWER, F. \& KOHLBERG, L. 1980. Religion, morality and ego development. (In Fowler, J. \& Vergote, A., eds. Towards moral and religious maturity. Morristown: Silver Burdett. p. 343-372.)

PRINSLOO, I.J. 2005. How safe are South African schools? South African Journal of Education, 25(1):5-10.

SCHOEMAN, P.G. 2000. Ideology, culture and education. Bloemfontein: Tekskor.

SCHUMACHER, E.F. 1974. Small is beautiful: a study in economics as if people mattered. London: Sphere Books.

SMEDES, L.B. 1990. A pretty good person. San Francisco: Harper \& Row.

TOUCHPOINT BIBLE. 1996. Wheaton: Tyndale House.

VAN DER VEN, J.A. 1998. Formation of the moral self. Grand Rapids: Eerdmans.

VAN DER WALT, J.L. 2000. Opvoeding vir die vroeg-21ste eeu: 'n Christelikopvoedkundige perspektief. Koers, 65(3):357-375.

VAN DYK, J. 2000. The craft of Christian teaching. Sioux Center: Dordt.

VOSLOO, R. 1995. Etiek en deugde: 'n kritiese ondersoek na aanleiding van die herwaardering van die deugde in morele besinning. Nederduitse Gereformeerde Teologiese Tydskrif, 36(2):272-283.

WILLIAMS, M.M. 1993. Action speaks louder than words: what students think. Educational Leadership, 51(3):22-23.

WYNNE, E. \& RYAN, K. 1992. Reclaiming our schools: a handbook on teaching character, academics and discipline. New York: Merril.

\section{Kernbegrippe:}

karakteropvoeding

moraliteit

onderwys

vestiging van waardes

\section{Key concepts:}

character education

education

instilling values

morality 